\title{
DEDUCTIVE AND INDUCTIVE JUDGMENTS AS BASIC CONCEPTS OF THE SUBJECT OF CRITICAL THINKING
}

\author{
Aidyn Aldaberdikyzy ${ }^{1}$, Zhazira Sagynova ${ }^{2}$ \\ ${ }^{1}$ L.N. Gumilev ENU, Nur-Sultan, Kazakhstan \\ ${ }^{2}$ Korkyt Ata Kyzylorda University, Kyzylorda, Kazakhstan \\ ORCID ID iD: 0000-0002-2991-5867 \\ ORCID ID iD: 0000-0002-2251-5537
}

\begin{abstract}
The article shows the importance of critical thinking and its structure in the modern educational process. Explicit approaches to the development of critical thinking, the foundations of deductive and inductive thinking are clarified. There are given the opinions about these methods in the works of scientists in the field of world pedagogy. The article also describes the structures of deductive and inductive reasoning and methods of rational use of them.
\end{abstract}

\section{INTRODUCTION}

Today it is very difficult to motivate students to engage in cognitive activities, independently and creatively seek ways to achieve goals in the constantly changing information and communication space. Students often face difficulties in mastering the teaching materials. This is due to the lack of a high level of judgment and, most importantly, critical thinking. The technology for the development of critical thinking is one of the pedagogical technologies that can solve the problem of an individual approach to learning and the effective achievement of personal results. This is based on the successful combination of technology and problem-based learning. Using the methods of technology for the development of critical thinking, the teacher arouses the student's interest, increases his desire to use a foreign language in practice, making it clear that he will be able to develop communicative competence in a foreign language. The technology for the development of critical thinking has significant potential for students to achieve individual results, which allows it to be widely used in foreign language lessons.

Critical thinking is a unique skill that allows us to master the requirements of the 21 st century, to better understand what we read and do. But what is critical thinking? Critical thinking is independent thinking. When a lesson is based on the principles of critical thinking, everyone articulates their ideas, values and beliefs independently of the others. Nobody can think critically for us, we can only do it for ourselves. Therefore, thinking can only be critical when it is personal. He is looking for convincing evidence. The critical thinker finds his own solution to the problem and affirms that solution on reasonable, well-founded grounds. He also understands that there are other ways to solve a problem and tries to prove that the solution he chooses is more logical and rational than others.

A.N. Schumann identifies three levels of critical thinking: deductive, inductive and dialectical. At the first level, critical thinking is tested for its own logical correctness, at the second - for the ability to process empirical data, at the third - for the subject's ability to discuss and convince opponents of the correctness of their views [Shuman, A.N., 2007].

Deductive and inductive judgment are methods of explicit approaches to the formation of grammatical skills and abilities. The name of the deductive method comes from the word "deduction", which means to draw conclusions from the general to the particular. The first stage of the formation of skills and abilities by the deductive method - familiarization - is carried out in the process of familiarization with the rules and examples, the second stage is training - processing of individual formal operations, the third stage is speech practice - translation of the exercise. 
Another explicit approach is inductive. The inductive method, like induction, takes the form of a conclusion, which involves the transition from individual facts to general rules. The inductive method allows students to create their own rules based on the phenomena that arise when learning a foreign language. Using the inductive method, students find unfamiliar grammatical forms in the text and try to understand their meaning through context. Further analysis of the new phenomenon is carried out by comparing a text in a foreign language with a translation into the native language, after which a new rule is formulated. In this case, the advice of a teacher or a textbook is used as needed. This is followed by a series of exercises to identify and explain a new grammatical phenomenon, to update its forms [Sakaeva, Baranova, 2016].

Induction makes you think and search, deduction gives ready-made facts, while for a person his personal experience is important, and therefore personal discovery is important. "Thinking begins where there is a problem situation," said D. Dewey, the founder of progressive pedagogy. The principle of "discovery", or "independent acquisition of knowledge by purposeful search for an answer to the problem posed by the teacher or by the students themselves" [Bim-Bad, B.M.], was recognized as a key factor in the success of the teaching: "The main thing is to help master those" facts that constitute the problem "and without imposing an external logical scheme on the mind that already understands the subject, on the mind that is struggling to understand it ", give freedom to put forward and test hypotheses" [Bim-Bad, B.M.]. D. Dewey's "school of action" puts forward the principle of "learning by doing", which is based on "doing," based on the process, not the result. The most important discovery of individual psychology, on which any learning should be based, Dewey formulated as follows: "The human brain is incapable of cognition if it is in a vacuum; the facts offered for study, for memorization, should have some relation to the person's previous experience or to her present needs; knowledge develops from the particular to the general, and not from the general to the particular" [Dewey, J.].

U. Decoo proposes to consider the traditional dichotomy "induction-deduction" in the educational process in an extended version, highlighting five subcategories [Decoo, 1996]:

- modality A: "actual deduction", which implies the explanation of the rule by the teacher at the beginning of the lesson, followed by practicing in the form of exercises;

- modality B: "conscious induction as a controlled "discovery", when examples of the use of a particular grammatical phenomenon are presented and, under the guidance of a teacher, with the help of leading questions, students discover and formulate a rule;

- modality C: "induction leading to the explicit expression of behavior" has its origins in behaviorism and the audio-lingual method. The student intensively trains in the use of a certain grammatical structure, translating through a similar practice the understanding of the rule to the level of inner awareness, after which the teacher gives an explicit explanation of this rule;

- modality D: "subconscious induction based on structured material". Students are provided with specially selected material, structured to facilitate the process of inductive learning. In doing so, they come to understand the meaning of the rule without further explicit analysis and explanation;

- modality E: "subconscious induction based on unstructured material" is actually identified with natural mastery of language, since it does not imply either teacher control or structuring of linguistic content.

R. Salaberry presents a somewhat modified set of the above modalities in the form of a continuous continuum:

rules $\Rightarrow$ metalinguistic awareness $\Rightarrow$ intensive training of language material $\Rightarrow$ structured data $\Rightarrow$ frequency [Gollin, J., 1998]. At the same time, there is a gradual transition from a completely explicit presentation of the material to a completely implicit assimilation of the language by students. In the first case, this is a conscious, open, purposeful assimilation of knowledge, in the second unconscious, intuitive mastery of the material using the appropriate strategies in both types of learning. 
M. Takimoto explains the difference in results by five factors: expectations, frequency, perception characteristics, level of proficiency, task requirements [Takimoto, 2008], and U. Decoo emphasizes the importance of variables representing two groups: "individual variables" and the content of education [Decoo, 1996].

Based on the above, J. Gollin, for example, makes a logical conclusion that "from one lesson to another and during the same lesson, a teacher can change approaches" [Gollin, 1998], using both inductive and deductive teaching techniques, i.e. it is not about the contradiction of methods, but about their complementarity.

\section{CONCLUSION}

Summarizing the above data, it should be noted that deductive and inductive thinking is particularly effective in the formation and development of critical thinking. In deductive reasoning, the student, based on his general knowledge and experience, evaluates the material as a whole and analyzes it individually. In an inductive approach, the student works collectively through the individual mechanisms of new information. When both approaches are correctly alternated by the teacher in the process of transferring new knowledge and explanations, the student not only assimilates new information, but also strengthens his critical thinking skills and learns to work critically in real life.

\section{REFERENCES:}

Bim-Bad, B.M. John Dewey as a pedagogue. http://www.bim-bad.ru/biblioteka/article_full.php?aid $=206,($ date of access $-31.10 .15)$.

Decoo, W. (1996) The induction-deduction opposition: ambiguities and complexities of the didactic reality. IRAL - International Review of Applied Linguistics in Language Teaching. (34) pp. 9698.

Dewey, J. (date of access - 31.10.15). Individual psychology and education. http://www.bimbad.ru/biblioteka/article_full.php?aid $=734$

Foreign Language Teaching Methods. Grammar / Lesson 3: Inductive Approaches to Teaching Grammar. Center for Open Educational Resources and Language Learning. The University of Texas at Austin. Assesed at: https://coerll.utexas.edu/methods/modules/grammar/03/

Gollin, J. (1998) Deductive vs. Inductive language learning. English Language Teaching Journal. (52) pp. 88 - 89.

Sakaeva, L.R., Baranova, A.R. (2016). Metodika obucheniya inostrannym yazykam. KFU.

Shuman, A.N. (2004). Sovremennaya logika: teoriya i praktika. Ekonompress.

Takimoto, M. (2008) The effects of deductive and inductive instruction on the development of language learners' pragmatic competence. The Modern Language Journal. (92) pp. 369-386. 